\title{
GENERAL ASSIGNMENTS AND THE BANKRUPTCY LAW
}

\author{
MARSHALL S. HAGAR \\ of the New York Bar

\section{INTRODUCTION}

Under the English Bankrupt Acts and our own Acts of $184 \mathrm{I}$ and 1867, a general assignment made by a debtor for the benefit of creditors was held almost uniformly to be an act of bankruptcy and a constructive fraud upon the bankruptcy law. This was true whether the assignment was made with or without preference, for the benefit of all or of only some of the creditors, and without regard to the debtor's actual intent in making it. It was considered an attempt on his part to defeat the operation of the bankruptcy statute by selecting his own administrator and the forum in which his estate was to be administered, with the preconceived purpose of securing to himself greater lenity and advantage through such administration, and the avoidance of the more stringent regulations of the bankruptcy courts; and thus it was deemed an attempt to hinder and delay his creditors. ${ }^{1}$ It was even held by the late eminent jurist; William $\mathrm{J}$. Wallace, when district judge in the Northern District of New York, that under the Act of 1867 , such an assignment was an act of bankruptcy which would defeat a discharge, irrespective of the time when it was made, and although made without preference. ${ }^{2}$ The assignee for the benefit of creditors, as a participant in such attempted fraud upon our earlier Acts, was held to strict accountability in respect to his disposition of the debtor's estate and his own expenditures, and was often refused compensation because of his connection with the common-law assignment.

Our present bankruptcy law provides in express words, among the enumeration of the acts of bankruptcy, that one of such acts shall consist in the debtor's having made a general assignment for the benefit of his creditors. ${ }^{3}$ To constitute such an act of bankruptcy, there

\footnotetext{
2 Jones v. Sleeper ( 1843 ) Fed. Cas. No. 7,496 (Act of I84I); MacDonald v. Moore (1876) Fed. Cas. No. 8,763 (Act of 1867 ); Globe Ins. Co. v. Cleveland Ins. Co. (I8j6) I4 Nat. Bankr. Reg. 3II, decision by Judge Blatchford (N. Y.), reversed on other grounds by Circuit Court of Appeals; Platt v. Preston (1879) Fed. Cas. No. II,219. See Mayer v. Hellman (1875) 9I U. S. 496, 502; In re, Biesenthal (1877) Fed. Cas. No. 1,236.

'In re Kasson (1878) I8 Nat. Bankr. Reg. 379.

Bankruptcy Act, July I, 1898, c. 54I, s. 3 (4).
} 
need be no formal deed of assignment, nor need the assignment necessarily be valid under the state law; and the assignment may be joined with an application for voluntary dissolution of a corporation in the state court. The term "general assignment" may be construed in a generic sense. ${ }^{5}$ It has also been held that after a general assignment is made, the act of bankruptcy is complete, and insolvency is not a defense to a bankruptcy petition, nor need it be alleged or proved. ${ }^{\circ}$ Although the making of a general assignment is no longer a ground for denying the bankrupt a discharge, the general principles and decisions affecting such general assignments under our former statutes in their relations to subsequent bankruptcy are as applicable under the present act as before.

\section{PARAMOUNT JURISDICTION OF THE FEDERAL COURT}

The Constitution of the United States expressly confers upon Congress power to make uniform bankruptcy laws throughout the states. $^{8}$

"The plenary and paramount power of congress to establish uniform laws. on the subject of bankruptcies throughout the United States, is given in express terms by the constitution of the United States. It is therefore very clear that when congress has exercised the power thus conferred their action must necessarily control or limit the exercise of the power of the states over the same subject matter; and that whenever any state legislation, or any action of the state courts, comes practically into actual conflict with the proper execution of the laws of congress, constitutionally passed under such grant of power, state legislation and the jurisdiction and action of the state courts must yield to the paramount authority of the national government. This being so it is unnecessary in this case to decide that the insolvent laws are superseded ipso facto by the bankrupt act."

This jurisdiction, though paramount, controlling and exclusive when properly invoked within the limited time, does not have the effect of repealing the state insolvency laws, but merely suspends

'In re C. H. Bennett Shoe Co. (1905) 140 Fed. 687; Courtenay Meriantile Co. v. Finch (1912) 27 Am. Bankr. Rep. 688; Grifin ข. Dutton (I908) I65 Fed. 626.

'In re Thomlinson Co. (1907) 154 Fed. 834, 835.

'Gill v. Farmers' \& Manufacturers' Bank (Igr5) 35 Am. Bankr. Rep. 9r; In re Farthing (I913) 202 Fed. 557.

This was declared in the noteworthy and exhaustive opinion of Judge Addison Brown of the Southern District of New York. In re Gutzillig (1898) I Am. Bankr. Rep. 78, aff'd id. 388. It was Judge Brown's privilege to determine many important and far-reaching questions arising in the first years of the operation of the present Bankruptcy Act; his opinions still stand illuminative of the subject and are often quoted and reiterated by the higher courts.

'In re Safe Deposit \& Savings Institution (1872) 7 Nat. Bankr. Reg. 393, 398. 
them pro tanto. Provisions of state statutes remain unaffected and controlling where bankruptcy does not intervene, and in some cases, even after such bankruptcy, as, for example, in respect to matters not comprised within the scope of the act. ${ }^{\circ}$.

On the other hand,

"the rights of creditors, inchoate from the making of the assignment, ripen into maturity when the adjudication is made. If it were otherwise the bankruptcy law could be evaded with the utmost facility."10

This being so, in such cases the assignee is not to be regarded, concerning matters occurring or transpiring after the filing of the petition, as an adverse claimant with any claim of right in himself or as an assignee for value, but as the agent for the debtor in the distribution of the estate. ${ }^{11}$

Upon an adjudication and the appointment and qualification of a trustee in bankruptcy, the title of the trustee to property in the hands of the assignee reverts to the date of the fling of the petition; all the trustee's rights and remedies are fixed as of that date, and the bankruptcy court has jurisdiction summarily to order such property delivered to the trustee, and to set aside a sale previously made by the assignee under certain circumstances and within the four months period. 12 Payments made by the assignee in apparent good faith may be recovered for the estate, and even a purchaser from an assignee may acquire no title as against the trustee in bankruptcy. ${ }^{13}$ Immediately after the filing of a bankruptcy petition, the federal court has power to enjoin the assignee from proceeding further with the subject of his assignment, or to appoint a receiver in bankruptcy; or in its discretion it may permit the assigned property to remain in the hands of the assignee pending the appointment of a trustee or other disposition of the estate.

\section{IIr. HISTORY OF ASSIGNMENTS SINCE THE BANKRUPTCY LAW OF I898 WENT INTO EFFECT}

Have our courts acted consistently in recognizing such paramount power of the federal courts? It would appear not if one closely

\footnotetext{
- In re Watts \& Sachs (I903) I90 U. S. I; In re Gray (I900) 3 Am. Bankr. Rep. 647.

${ }^{20}$ In re Knight (1903) I25 Fed. 35, 40. See Johnson v. Crawford \& Yothers (1907) I54 Fed. 76r, aff'd id. 769; Geo. M. West Co. v. Lea Bros. (1899) 174 U. S. 590.

${ }^{11}$ Bryan v. Bernheimer (Igor) I8r U. S. I88; Whittlesey v. Becker \& Co. (IgII) 25 Am. Bankr. Rep. 672.

${ }_{12}$ In re Knight (1903) I25 Fed. 35; In re Karp. (1915) 36 Am. Bankr. Rep. 4I4.

${ }^{23}$ Stearns v. Flick (1900) 103 Fed. 919; Ith re Knight, supra; In re Carver \& Co. (rgo2) 7 Am. Bankr. Rep. 539.
} 
observe the judicial attitude over a course of years. In the early years of administration under the Act of $I 898$, the making of general assignments by debtors was so generally frowned upon by the federal courts, following the trend of decisions under former acts, that it fell into general disuse. The assignment bureaus of the state courts became to a large extent deserted. Insolvency laws remained in most states upon the statute books, but few thought seriously of making a general assignment except as an easy step into a bankruptcy considered inevitable. In assignment cases the federal courts in most jurisdictions appointed bankruptcy receivers ex parte, with systematic regularity and without much scrutiny of the applications presented. It was enough that an assignment had been made and that an assignee was administering the estate, which, by every established principle of the Bankruptcy Act, Congress had intended to be administered under the exclusive authority of the federal courts. No thought was given to the personality or qualifications of the assignee, be he ever so eminently fitted to administer the estate, except that in rare cases he was named as receiver in the bankruptcy proceedings. Such was the modus operandi of the federal courts down to the end of the year rgog or the beginning of rgro, and throughout these years voluntary bankruptcy was not allowed to corporations: ${ }^{14}$ Meanwhile the expenses of bankruptcy receiverships multiplied and grew to abnormal amounts. Many complaints began to be heard as to the extreme cost of administering insolvent estates under this system and some reforms were projected, particularly in the Southern District of New York. In December, I9o9, the Circuit Court of Appeals for the Second Circuit handed down a decision in the matter of the Oakland Lumber Co., ${ }^{15}$ which was taken-mistakenly, it now appears-as establishing a new rule relating to assignments, and as restoring them once more to respectability. In the Oakland Co. case the court said:

"The question broadly stated, is this-should the court have vacated the ex parte order appointing the receiver?

"At the time this motion was made the questions presented by the creditors' petition and the bankrupt's answer were undetermined, and, so far as this record discloses, there was nothing to indicate that the assignee under the state law was not an honest, capable and responsible man, in whose hands the property was entirely safe.

"The power to take from a man his property, without giving him an opportunity to be heard, is both arbitrary and drastic and should not be exercised except in the clearest cases. Congress recognized the necessity for caution by limiting the appointment of receivers to cases

\footnotetext{
"By the amendment of I9Io corporations were permitted to become voluntary bankrupts, except municipal, railroad, insurance and banking corporations.

${ }^{15}$ In re Oakland Lumber Co. (1909) 174 Fed. 634, referring therein to an earlier decision of the same court, In re Spalding (I905, C. C. A. 2d) I39 Fed. 244.
} 
where it is 'absolutely necessary' for the preservation of the estate. In other words, the reason for such an interference with the rights of property must be clear, pośitive and certain. Of course cases frequently arise where this remedy may be necessary-cases where there is reason to believe that the property may be stolen, or secreted or turned over to favored creditors. But fraud cannot be presumed, neither can danger to the property be predicated of acts which are honest and lawful. It cannot be presumed that an assignee under a state law intends to plunder the fund he is appointed to administer. Unless something be shown to the contrary the presumption is persuasive that during the interval between the filing of the petition and the appointment of a trustee, the property will be entirely safe in the hands of the assignee, especially if he be enjoined from disposing of it pendente lite."

While upon examination of this case we find that it does but reiterate general and well-established principles of law which should govern the drastic remedy of receiverships, nevertheless the effect of the decision was almost revolutionary. The decision was apparently taken as establishing a general rule in favor of the retention of assignees and receivers appointed in the state court. It was thought to mean, generally speaking, that in no case should they thereafter, on the filing of a petition in bankruptcy, be removed or superseded by a receiver appointed in such bankruptcy proceedings without actual proof of fraud, misconduct or incompetency. Motions for the appointment of receivers in the district courts upon estates in the hands of assignees were denied with such frequency and uniformity that soon such motions almost ceased to be made. Many other restrictive rules were made as to the employment of the attorney for the petitioning creditors, as to the amount of compensation, etc., all tending to discourage attorneys seeking to invoke the aid of the federal courts in administering the estates of insolvents. These rulings soon drove the Bar and the commercial community to the opposite extreme. Only infrequent efforts were made to prevent assignees from administering estates in the state courts untrammelled, without fear of interference, and in the face of the bankruptcy law whose only utility under the circumstances might be to afford the debtor a discharge from his debts without the concomitant administration and investigation prior to the appointment of the trustee. In consequence of this attitude and of the interpretation of the Oakland Lumber Co. decision, the assignment business of the state courts increased enormously.

As stated recently in the public press of New York City, summing up statistics of assignments, in the year rgro in New York County there were seventy-seven general assignments; in IgIT one hundred and nine; in I912 one hundred and ninety-eight; in 1913 two hundred and forty-nine; in I9I4 nine hundred and twenty-four, and in r9I5 more than eleven hundred; while the number of assignments made in the county when the decision above referred to was written was 
trifling. In 1916 the number of corporations alone making assignments was two hundred and sixty-two.18

Abuses and evils arising from this double administration of the same subject-matter by state and federal courts became prevalent: assignees in some instances administered and distributed estates without even filing the bond required by state statute, sold property after the entry of the order of adjudication and without appraisal, made exorbitant payments to their attorneys, and succeeded, in some instances, in having their accounts passed and allowances fixed in the state courts even over the trustee's objection. Recently the federal courts, taking full cognizance of this unsavory state of affairs and the resulting loss to creditors, have been endeavoring to rectify and curb such evils. In 1916, in the matter of the Federal Mail \& Express Co., ${ }^{17}$ in the Southern District of New York, the court discussed these matters very explicitly in its opinion and stated as its conclusion that the decision of the Circuit Court of Appeals in the Oakland Lumber Co. case was not meant to interpose a jurisdictional objection to

"As to the methods employed in some of these assignment cases, considerable light is thrown by the record of a proceeding which the writer recently had occasion to examine in one of our district courts which may be taken, perhaps, as somewhat typical of many of the cases. In this particular case the attorney for the insolvent appeared with his client at the office of another attorney, a business acquaintance, and stated that his client desired to make a general assignment for the benefit of creditors to the latter attorney; and upon consent of this attorney, the assignment was made to him about four o'clock in the afternoon. Another attorney on a different floor in the same building was called up on the telephone by the assignee and told of the general assignment. This attorney with great expedition called at the office of the assignee, looked over the list of creditors, and was enabled by ten o'clock the following morning to file a petition in bankruptcy against the debtor upon three claims, all assigned to clerks in his own office. Immediately thereafter the assignee retained the lawyer acting as attorney for the petitioning creditors as his attorney also. While the assignee was on the stand in the bankruptcy proceeding, the following interesting colloquy took place:

"I anticipated that if any of Mr. - 's clients were interested in this assigned business. that a petition would be filed. $Q$. Was anything said about that between you and Mr. when I told him that I am assignee, he asked me, "whether any of his clients pere interested in the assignment' I said 'look them over; I don't know: I simply anticipated that he asked that question for the purpose of filing petition in bankruptcy; because he usually does. $Q$. What do you mean? $A$. What do I mean? That if any attorney who represents creditors sees that an assignment for the benefit of creditors is made, it is his duty to creditors to file a petition in bankruptcy. $Q$. Yes, but as I understand it, Mr.

represents you 'as assignee? $A$. Yes, I told you $I$ asked him to represent me in this as assignee, of course. - $: Q$. When was the first assignment for benefit of creditors made to you? Do you remember? A. A week after the custom was established. $Q$. When was that? $A$. Oh, I don't know, about two or three weeks after Judge would not permit the receiver to retain counsel. $Q$. How many assignments have been made to you since that time, approximately? A. May I ask my clerk? Of course I cannot teli, but there are fifty, perhaps one hundred. I think it is nearer one hundred, I don't want to be bound by this answer. . ."

${ }^{17}$ (I916) 37 Am. Bankr. Rep. 240. 
the general appointment of receivers when assignees were in charge, but was intended for that particular case. The district judge concluded by observing that he would be inclined to grant stays against assignees in case of future assignments, unless the creditors should as a body desire otherwise. This was followed by Judge Mayer in In re $D$. \& $E$. Dress Co., Inc., who remarked very pertinently :18

"An exceedingly annoying practice has developed by which, after the making of the general assignment, this court [Bankruptcy Court] is nevertheless appealed to either by the assignee or by creditors to assist in the speedy administration of the estate, which often is both necessary and important in connection with summary proceedings, by landlords, sales of perishable property, examinations and the like. . .

"I may also add that there may, of course, be cases where the selection of an assignee at a meeting of reliable creditors may be had under circumstances practically equivalent to the election of a trustee, but, reserving the discretion which may be necessary for exercise in any given case, I announce the general policy of removing assignees and appointing receivers in their stead, quite irrespective of the good. faith and standing of the assignee. This I think is the only means whereby the Bankruptcy Act can be carried out in accordance with its intent and spirit."

Through the concerted efforts of credit men of large commercial houses and attorneys practicing in bankruptcy, an attempt was recently made by Congress to have enacted certain amendments to the Bankruptcy Act whereby it should be obligatory upon the federal courts to take jurisdiction of the administration of assigned estates immediately upon the filing of the bankruptcy petition. In the press of more important matters, the amendment failed of passage, but it is to be hoped it will be taken up and considered at the next session of Congress.

\section{IN WHAT COURT ASSIGNEE SHOULD ACCOUNT}

Owing to the early decisions of the Supreme Court in Louisville Trust Co v. Comingor ${ }^{19}$ and Mueller v. Nugent ${ }^{20}$ the impression has prevailed that it was a matter of discretion on the part of the assignee whether he should account in the federal court or in the court which appointed him, and many of the cases in the books turn upon the point whether an assignee, having consented to come within the federal jurisdiction for the purpose of having his accounts passed, is bound by the summary order of such court in the matter of turning over assets, of recovering payments previously made by the assignee and disallowed, and in the surcharge of the assignee generally, by reason

${ }^{18}$ (July 5th, I9I6) N. Y. LAw J.

${ }^{19}$ (I902) I84 U. S. I8.

${ }^{20}$ (1902) I84 U. S. I. See also Bryan v. Bernheimer (Ig0r) I8I U. S. I88. 
of his misconduct in administering the assigned estate. For example, in the case of the Banzai Mfg. Co., ${ }^{22}$ the Circuit Court of Appeals for the Second Circuit considered an order made by the court below, that the assignee summarily turn over to the trustee several thousand dollars, much of which had been improvidently expended by the assignee and with which, for that reason, he had been surcharged. The court said:

"By reason of his [the assignee's] improvident conduct in so doing it has been foumd that he ought to make good to the estate the whole or the greater part of these disbursements, and he is a debtor to the estate for that amount, but it does not necessarily follow that his indebtedness is of such a sort that he may, be imprisoned for nonpayment. The situation differs from that which has frequently come before the courts where a person-the bankrupt or some one elsehas had property of the estate in his possession and testifies that he had paid it out or distributed it in some way, but the referee and the district judge have disbelieved his testimony and have ordered him to return the property or be imprisoned for disobedience to such order. It is not understood that in the case at bar the trustee disputes the statement of [the assignee] that he actually did pay out the money, or substantially all of it. More would be required than appears in this record to warrant an order punishing [the assignee] for failure to pay $\$ 6,053.27$ which he owes the estate as a result of his transactions while assignee."

This entire matter of jurisdiction to settle an assignee's accounts has recently come before the courts in the matter of Louis Neuburger, Inc. ${ }^{22}$ wherein an assignee filed his report and accounts in the Bronx County Court, New York, and an order was entered passing and approving such accounts over the trustee's objection. The assignee thereupon served upon the trustee in bankruptcy a copy of the order passing his accounts, and paid over a check for the monies payable to the trustee, pursuant to the order. Subsequently the referee in bankruptcy, upon the application of the trustee, directed the assignee to file his report and accounts as assignee in the United States District Court on or before a certain date. The assignee refused to comply with this order; his application for a review of the order was heard and denied, the district judge overruling the contention of the assignee that he had a right to account only in the state court, whence he derived his authority. The court held that the trustee had the power to compel an accounting in the federal court, and that the state court having been ousted in its jurisdiction, the accounting order of the state court was not binding upon the trustee as res adjudicata. The Circuit Court of Appeals, Second Circuit, with opinion by Judge Rogers,

21 (I9I0) 25 Am. Bankr. Rep. 497, 50 .

2 (1916) 37 Am. Bankr. Rep. 248, aff'd (I9!7) 39 Am. Bankr. Rep. 139. 
affirmed the court below and held that it was the plain duty of the assignee to account in the bankruptcy court for the estate which came into his hands as assignee.

\section{COMPENSATION OF ASSIGNEE AND HIS ATTORNEY IN THE BANKRUPTCY COURT}

It was formerly held in many jurisdictions ${ }^{23}$ that an assignee's claim for compensation for his services must, when bankruptcy has intervened, be disallowed, upon the theory that the assignee by his acceptance of the assignment voluntarily makes himself a party to an arrangement contrary to the policy of Congress in enacting a uniform bankruptcy law, and that assignees should go unrewarded even when they have acted honestly and intelligently and in all probability the estate has benefited by their experience and efforts. This harsh rule was soon modified, however, and it is now quite generally held that an assignee should be treated, upon the settlement of his account, as a quasi-receiver and be compensated, together with his attorney, for whatever services are shown to have been of actual benefit in preserving the estate while in his possession. To be denied compensation he must have been guilty of actual fraud, waste or negligent conduct. His claim, however, is not entitled to be paid as a first lien or claim in the bankruptcy courts out of the estate in the hands of trustee; nor can there be any deduction for services rendered by the assignee prior to the assignment or for expenses made in attempting to resist an adjudication in bankruptcy. ${ }^{24}$ As' to disbursements made prior to the four months preceding bankruptcy, the Supreme Court has held that in such cases the assignee is an adverse claimant and such dishursements cannot be recovered in summary proceedings. ${ }^{25}$

\section{DUTIES AND LIABILITIES OF ASSIGNEES IN RELATION TO INSOLVENT'S ESTATE}

While Congress has not, by enacting a uniform bankruptcy system, succeeded, it seems, in outlawing the state insolvency laws, nevertheless it has made it incumbent on a state court assignee to act with the utmost good faith and sound business judgment in administering his trust, if he is to avoid liability. He will be held to have acted on notice and at his peril in carrying on the bankrupt's business, in selling

"In re Pauly (1899) 2 Am. Bankr. Rep. 333; In re Kingman (1899) 5 Am. Bankr. Rep. 25I; In re Peter Paul Book Co. (I900) 5 Am. Bankr. Rep. I05; In re Harson Co. (Ig04) II Am. Bankr. Rep. 5I4; Wilbur v. Watson (1901) 7 Am. Bankr. Rep. 54.

24 In re Hays (Igro) 24 Am. Bankr. Rep. 69r.

${ }^{*}$ Louisville Trust Co.v. Comingor (Ig02) 184 U. S. 18; Randolph v. Scruggs (Ig03) 10 Am. Bankr. Rep. I; In re Zier \& Co. (Ig05) I5 Am. Bankr. Rep. 646. 
it out, or in making expenditures. He may be surcharged for resulting losses or for doing anything beyond what was necessary to preserve the property which was in his hands when the petition was filed. Under ordinary circumstances it is his duty to turn this over intact to the trustee in bankruptcy. ${ }^{28}$

* In re Karp (Igr5) 36 Am. Bankr. Rep. 4r4; In re Sobol (19r5) 35 Am. Bankr. Rep. 804; In re Resnek (I9I7) 38 Am. Bankr. Rep. 759; In re Hays (IgI0) I8I Fed. 674 